\title{
The Effenberger's synthesis of 3,3'-bipyrazole revisited
}

\author{
Virginie Vicente, ${ }^{a}$ Alain Fruchier, ${ }^{a}$ and José Elguero ${ }^{b}$ \\ ${ }^{a}$ UMR 5076, E.N.S.C.M., 8 rue de l'Ecole Normale, F-34296 Montpellier Cedex 5, France, and \\ ' Centro de Química Orgánica 'Manuel Lora-Tamayo', \\ Juan de la Cierva 3, E-28006 Madrid, Spain
}

Dedicated to Professor Mieczyslaw Makosza on his $70^{\text {th }}$ anniversary

(received 19 May 03; accepted 14 Aug 03; published on the web 11 Sept 03)

\begin{abstract}
When 1,4-bis-ethoxymethylen-2,3-butanedione 2 reacts with hydrazine, following a slightly modified Effenberger's procedure, other compounds than the expected 3,5'-bipyrazole 1 are obtained. This paper describes the isolation, besides 1, of two pyridazinones and one 6H-6,7dihydropyrazolo[1,5- $d]$-1,2,4-triazine and the determination of their structure by mass spectrometry and by ${ }^{1} \mathrm{H}$ and ${ }^{13} \mathrm{C}$ NMR.
\end{abstract}

Keywords: Effenberger's procedure, bipyrazoles, pyridazinones, pyrazolotriazines

\section{Introduction}

There are six derivatives of bipyrazole 1 which differ from the position of the C-C bond between the two pyrazole rings (Scheme 1).
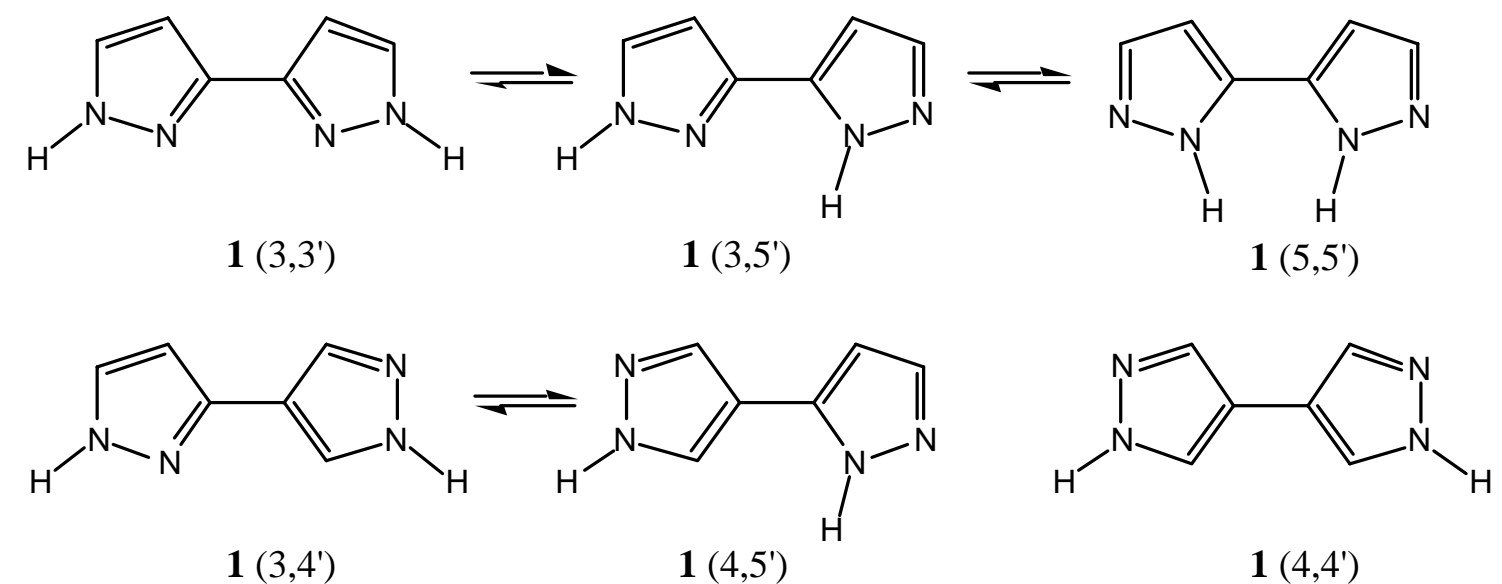

Scheme 1

All of these compounds, except the 4,4'-derivative, exist separately when they are $N$ - 
substituted, but the $\mathrm{NH}$ forms represented in Scheme 1 are subject to annular tautomerism. ${ }^{1}$ All of them have been prepared: the family of 3,3'-, 3,5'- and 5,5'- derivatives by many authors, generally with substituents on the carbon atoms, ${ }^{2-12}$ the $3,4^{\prime}-\left(4,5^{\prime}-\right)$ family less frequently ${ }^{6,13,14}$ and, finally, 4,4'-bipyrazoles being again quite common., ${ }^{6,-22}$ The parent compounds are described for 3,3'-bipyrazole ${ }^{2,7,11}$ and 4,4'-bipyrazole ${ }^{16,18-20}$ but that of 3,4'-bipyrazole has not been prepared yet. All of these compounds have important uses in coordination chemistry as polydentate ligands.

3,3'-Bipyrazole 1 (3,3') has been reported three times. Effenberger ${ }^{2}$ prepared it from 1,4-bisethoxymethylenbutane-2,3-dione 2 and hydrazine with a yield of 75\% (60\% after crystallization) and a m.p. of $257{ }^{\circ} \mathrm{C}$. Then Wille and Schwab ${ }^{7}$ obtained 1 from 1,1,6,6-tetraethoxy-2,4hexadiyne and hydrazide hydrochloride with a yield of $34 \%$ and reported its ${ }^{1} \mathrm{H}$ NMR spectrum in DMSO- $d_{6}$ but not its melting point. Finally, some of us prepared again $\mathbf{1}$ using the Effenberger's procedure, determined its X-ray structure and discussed its tautomerism in solution. ${ }^{11}$ We should note that Habraken et al. ${ }^{6}$ prepared the three bis- $N$-methyl derivatives of $\mathbf{1}$ (3,3'-, 3,5'- and 5,5'-) using the method of Effenberger with methylhydrazine instead of hydrazine, the total yield being between 25 and 34\%. Since we needed compound 1 for synthesizing new ligands, we decided to prepare it again.

\section{Results and Discussion}

Effenberger's synthesis of hydrazine is reported like this: ${ }^{2}$ First, free hydrazine was prepared adding sodium methoxide in methanol $(1.84 \mathrm{~g}$ of sodium, $80 \mathrm{mmol}$, in $40 \mathrm{~mL}$ of anhydrous methanol) to $4.2 \mathrm{~g}$ (40 mmol) of hydrazonium dichloride in $10 \mathrm{~mL}$ of anhydrous methanol. Sodium chloride was filtered off and the methanolic hydrazine solution was cooled down to $-10{ }^{\circ} \mathrm{C}$ and $1.98 \mathrm{~g}(10 \mathrm{mmol})$ of 1,4-bis-ethoxymethylen-butane-2,3-dione 2 in $20 \mathrm{~mL}$ of anhydrous ether was added. The solution was kept at $-\mathbf{1 0}{ }^{\circ} \mathbf{C}$ for $24 \mathbf{h}$. Compound 1 precipitates: 1.0 g (75\% yield), m.p. $257^{\circ} \mathrm{C}$. Crystallized from ethanol, 0.8 g (60\% yield), pure 1 m.p. $261^{\circ} \mathrm{C}$.

Following exactly this procedure, an identical result was obtained, but if instead of keeping the solution at $-10{ }^{\circ} \mathrm{C}$ for $24 \mathrm{~h}$, the solution was abandoned at room temperature (in our case $21^{\circ} \mathbf{C}$ ), then nothing precipitates. The solution was evaporated to dryness and a orange solid was obtained. A ${ }^{1} \mathrm{H}$ NMR of the crude in DMSO- $d_{6}$ shows that it is a $55-30-15 \%$ mixture of three compounds (A-B-C). When the crude was dissolved in acetone and evaporated, compound $\mathbf{B}$ (30\%) disappeared and two new compounds $\mathbf{D}$ and $\mathbf{E}$, in comparable proportions, were formed, the first one evolving on standing to $\mathbf{E}$. These compounds were isolated by flash chromatography, but B proved too unstable to be fully characterized. We have determined the structure of all these compounds by a combination of mass spectrometry and ${ }^{1} \mathrm{H}$ and ${ }^{13} \mathrm{C}$ NMR: $\mathbf{A}$ is $\mathbf{3}, \mathbf{B}$ is probably $\mathbf{4}, \mathbf{C}$ is the desired $\mathbf{1 ,} \mathbf{D}$ is $\mathbf{5}$ and $\mathbf{E}$ is $\mathbf{6}$ (see Scheme 2).

We have found another procedure to prepare $\mathbf{1}$ which uses hydrazine hydrate: $40.0 \mathrm{mmol}$ of hydrazine hydrate in $12 \mathrm{~mL}$ of THF were added to $20.0 \mathrm{mmol}$ of diketone 2 and a few grains of p-toluenesulfonic acid in $20 \mathrm{~mL}$ of anhydrous THF. The mixture was left under stirring for $24 \mathbf{h}$ 
at room temperature and then filtered off. The insoluble solid was washed with THF and dried under vacuum. Bipyrazole $\mathbf{1}$ was obtained with a yield of $75 \%$ (note that once in the solid state, $\mathbf{1}$ is a very insoluble compound).

The different compounds and their numbering are reported in Scheme 2. Postulated intermediaries are in brackets; compound $\mathbf{4}$ has no numbering system because no NMR spectrum could be obtained.<smiles>c1cc(-c2cc[nH]n2)[nH]n1</smiles>

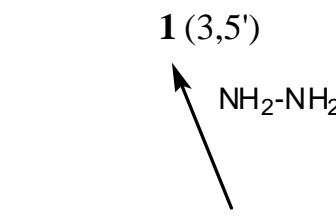<smiles>CCOC=CC(=O)c1ccn[nH]1</smiles><smiles>[CH]=C</smiles><smiles>CCOC(C)C(C)OC</smiles><smiles>C=C(c1nnccc1C=NN)C(OCC)OCC</smiles><smiles>NN=CC(N)=O</smiles><smiles>[2H]c1cnn(C)c1/C(=N/N=C(C)C)[C@H](C)[C@H](O)OC(C)(C)C</smiles><smiles></smiles>

$3, \mathrm{R}=\mathrm{CH}_{3}$

$7, \mathrm{R}=\mathrm{C}_{2} \mathrm{H}_{5}$

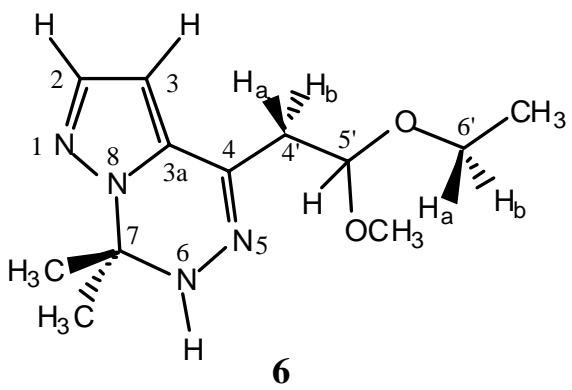

Scheme 2 
Identification of the diferent compounds. Compound 1 (m.p. 258-260 ${ }^{\circ} \mathrm{C}$ ) was identified by comparison with an authentic sample. ${ }^{11}{ }^{1} \mathrm{H}$ NMR (DMSO- $d_{6}$ ): $\delta 12.97$ (broad s, NH); 7.66 (broad s, H-5); 6.54 (d, $\left.{ }^{3} J=2.1 \mathrm{~Hz}, \mathrm{H}-4\right) .{ }^{13} \mathrm{C}$ NMR (DMSO- $d_{6}+1$ drop of $\mathrm{CF}_{3} \mathrm{CO}_{2} \mathrm{H}$ ): $\delta 141.41$ (C-5); 133.26 (C-3); 102.69 (C-4).

Compound 3 ( $\mathrm{R}=\mathrm{CH}_{3}$, m.p. 114-115 $\left.{ }^{\circ} \mathrm{C}\right)$. HRMS m/z $198.1019\left(\mathrm{C}_{9} \mathrm{H}_{14} \mathrm{~N}_{2} \mathrm{O}_{3}\right)$ requires 198.1004. NMR ( $\left.\mathrm{CDCl}_{3}\right):{ }^{1} \mathrm{H} \delta 6.52$ (d, $\left.{ }^{3} J=7.3 \mathrm{~Hz}, \mathrm{H}-5\right), 7.97$ (d, $\left.{ }^{3} J=7.3 \mathrm{~Hz}, \mathrm{H}-6\right), 3.14$ (d, ${ }^{3} J$ $=5.8 \mathrm{~Hz}$ with $\mathrm{H}-2$ ', $\mathrm{H}_{\mathrm{a}}$ and $\mathrm{H}_{\mathrm{b}}$ on $\left.\mathrm{C}-1^{\prime}\right), 5.09$ (t, ${ }^{3} \mathrm{~J}=5.8 \mathrm{~Hz}$ with $\mathrm{H}_{\mathrm{a}}$ and $\mathrm{H}_{\mathrm{b}}$ on $\left.\mathrm{C}-1^{\prime}, \mathrm{H}-2{ }^{\prime}\right), 3.38$

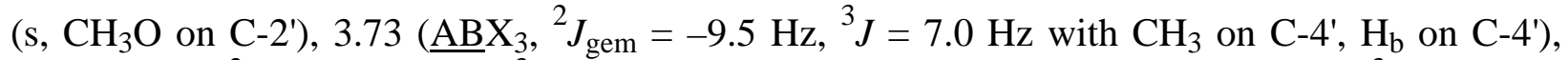
$3.59\left(\underline{\mathrm{ABX}}_{3},{ }^{2} J_{\text {gem }}=-9.5 \mathrm{~Hz},{ }^{3} \mathrm{~J}=7.0 \mathrm{~Hz}\right.$ with $\mathrm{CH}_{3}$ on $\mathrm{C}-4{ }^{\prime}, \mathrm{H}_{\mathrm{a}}$ on $\left.\mathrm{C}-4\right), 1.20\left(\mathrm{t},{ }^{3} \mathrm{~J}=7.0 \mathrm{~Hz}\right.$ with $\mathrm{H}_{\mathrm{a}}$ and $\mathrm{H}_{\mathrm{b}}$ on $\mathrm{C}-4$ ', $\mathrm{CH}_{3}$ on $\mathrm{C}-4$ '). ${ }^{13} \mathrm{C} \delta 157.01$ (C-3), 171.57 (C-4), 114.25 (C-5), 139.81 (C-6), 34.89 (C-1'), 100.78 (C-2'), $52.96\left(\mathrm{CH}_{3} \mathrm{O}\right.$ on $\left.\mathrm{C}-2^{\prime}\right), 61.72$ (C-4'), $15.18\left(\mathrm{CH}_{3}\right.$ on $\left.\mathrm{C}-4^{\prime}\right)$. Note that in compound $3, \mathrm{H}_{\mathrm{a}}$ and $\mathrm{H}_{\mathrm{b}}$ on $\mathrm{C}-1$ ' are diastereotopic but accidentally isochronous at $250 \mathrm{MHz}$.

Compound 7 ( $\mathrm{R}=\mathrm{C}_{2} \mathrm{H}_{5}$, m.p. 119-120 $\left.{ }^{\circ} \mathrm{C}\right)$. HRMS m/z $212.1140\left(\mathrm{C}_{10} \mathrm{H}_{16} \mathrm{~N}_{2} \mathrm{O}_{3}\right)$ requires 212.1161. NMR ( $\left.\mathrm{CDCl}_{3}\right):{ }^{1} \mathrm{H} \delta 6.51$ (d, $\left.{ }^{3} J=7.4 \mathrm{~Hz}, \mathrm{H}-5\right), 7.98$ (d, $\left.{ }^{3} J=7.4 \mathrm{~Hz}, \mathrm{H}-6\right), 3.13$ (d, ${ }^{3} J$ = $5.9 \mathrm{~Hz}$ with $\mathrm{H}-2^{\prime}, \mathrm{H}_{\mathrm{a}}$ and $\mathrm{H}_{\mathrm{b}}$ on $\left.\mathrm{C}-1^{\prime}\right), 5.137$ (t, ${ }^{3} \mathrm{~J}=5.9 \mathrm{~Hz}$ with $\mathrm{H}_{\mathrm{a}}$ and $\mathrm{H}_{\mathrm{b}}$ on $\mathrm{C}-\mathrm{1}^{\prime}, \mathrm{H}-2$ '), 3.72 $\left(\underline{\mathrm{ABX}}_{3},{ }^{2} J_{\text {gem }}=-9.5 \mathrm{~Hz},{ }^{3} J=7.1 \mathrm{~Hz}\right.$ with $\mathrm{CH}_{3}$ on $\mathrm{C}-4{ }^{\prime}, \mathrm{H}_{\mathrm{b}}$ on $\left.\mathrm{C}-4\right), 3.56\left(\underline{\mathrm{ABX}}_{3},{ }^{2} J_{\text {gem }}=-9.5\right.$ $\mathrm{Hz},{ }^{3} \mathrm{~J}=7.1 \mathrm{~Hz}$ with $\mathrm{CH}_{3}$ on $\mathrm{C}-4{ }^{\prime}, \mathrm{H}_{\mathrm{a}}$ on $\mathrm{C}-4$ '), 1.16 (t, ${ }^{3} \mathrm{~J}=7.1 \mathrm{~Hz}$ with $\mathrm{H}_{\mathrm{a}}$ and $\mathrm{H}_{\mathrm{b}}$ on $\mathrm{C}-4$ ', $\mathrm{CH}_{3}$ on C-4'). ${ }^{13} \mathrm{C} \delta 156.79$ (C-3), 171.52 (C-4), 113.99 (C-5), 140.29 (C-6), 35.41 (C-1'), 100.04 (C2'), $61.38\left(\mathrm{C}-4\right.$ '), $15.07\left(\mathrm{CH}_{3}\right.$ on $\mathrm{C}-4$ '). Note that in compound 7 the two OEt group on $\mathrm{C}-2$ ' are enantiotopic just as $\mathrm{H}_{\mathrm{a}}$ and $\mathrm{H}_{\mathrm{b}}$ on $\mathrm{C}-\mathrm{1}^{\prime}$, but that $\mathrm{H}_{\mathrm{a}}$ and $\mathrm{H}_{\mathrm{b}}$ on each OEt group are diastereotopic.

Compound 4 was not isolated, only a GC/MS spectrum was obtained, $213 \mathrm{Da}[\mathrm{M}+\mathrm{H}]^{+}$, calculated for $\mathrm{C}_{9} \mathrm{H}_{16} \mathrm{~N}_{4} \mathrm{O}_{2}, \mathrm{~m} / \mathrm{z}=212.1 \mathrm{Da}$.

Compound 5 (oil). HRMS m/z $252.1579\left(\mathrm{C}_{12} \mathrm{H}_{20} \mathrm{~N}_{4} \mathrm{O}_{2}\right)$ requires 252.1586. NMR $\left(\mathrm{CDCl}_{3}\right)$ : ${ }^{1} \mathrm{H} \delta 6.66\left(\mathrm{~d},{ }^{3} \mathrm{~J}=2.1 \mathrm{~Hz}, \mathrm{H}-4\right), 7.535\left(\mathrm{~d},{ }^{3} \mathrm{~J}=2.1 \mathrm{~Hz}, \mathrm{H}-3\right), 1.90$ and $2.05\left(\mathrm{CH}_{3}\right.$ groups on C-5'), 3.27 (s, $\mathrm{CH}_{3} \mathrm{O}$ on $\left.\mathrm{C}-3^{\prime}\right), 3.159\left(\mathrm{~m},{ }^{2} J_{\text {gem }}=-12.7 \mathrm{~Hz},{ }^{3} J=5.7 \mathrm{~Hz}\right.$ with $\mathrm{H}-3$ ', $\left.\mathrm{H}_{\mathrm{a}}\right), 3.11$ ( $\underline{\mathrm{ABX}}$, ${ }^{2} J_{\text {gem }}=-12.7 \mathrm{~Hz},{ }^{3} J=5.7 \mathrm{~Hz}$ with $\left.\mathrm{H}^{-} \mathrm{3}^{\prime}, \mathrm{H}_{\mathrm{b}}\right), 4.76\left(\mathrm{t},{ }^{3} \mathrm{~J}=5.7 \mathrm{~Hz}\right.$ with $\mathrm{H}_{\mathrm{a}}$ and $\mathrm{H}_{\mathrm{b}}$ on $\mathrm{C}-2$ ', $\left.\mathrm{H}-3^{\prime}\right)$, $3.62\left(\underline{\mathrm{ABX}}_{3},{ }^{2} J_{\text {gem }}=-9.4 \mathrm{~Hz},{ }^{3} J=7.0 \mathrm{~Hz}\right.$ with $\mathrm{CH}_{3}$ on $\left.\mathrm{C}-4{ }^{\prime}, \mathrm{H}_{\mathrm{b}}\right), 3.43\left(\underline{\mathrm{ABX}_{3}},{ }^{2} J_{\text {gem }}=-9.4 \mathrm{~Hz}\right.$, ${ }^{3} J=7.0 \mathrm{~Hz}$ with $\mathrm{CH}_{3}$ on $\left.\mathrm{C}-4{ }^{\prime}, \mathrm{H}_{\mathrm{a}}\right), 1.09$ (t, ${ }^{3} J=7.0 \mathrm{~Hz}$ with $\mathrm{H}_{\mathrm{a}}$ and $\mathrm{H}_{\mathrm{b}}$ on $\mathrm{C}-4$ ', $\mathrm{CH}_{3}$ on C-4'). ${ }^{13} \mathrm{C} \delta 145.44$ (C-5), 105.14 (C-4), 135.23 (C-3), 151.36 (C-1'), 33.83 (C-2'), 101.55 (C-3'), 62.13 (C-4'), 53.41 ( $\mathrm{CH}_{3} \mathrm{O}$ on $\left.\mathrm{C}-3^{\prime}\right), 15.00$ ( $\mathrm{CH}_{3}$ on $\mathrm{C}-4$ '), 162.43 (C-5'), 25.02 and 18.59 ( $\mathrm{CH}_{3}$ groups on $\left.\mathrm{C}-5^{\prime}\right)$.

Compound 6, 6H-6,7-dihydropyrazolo[1,5-d]-1,2,4-triazine, m.p. 132-134 ${ }^{\circ} \mathrm{C}$. HRMS m/z 252.1618 $\left(\mathrm{C}_{12} \mathrm{H}_{20} \mathrm{~N}_{4} \mathrm{O}_{2}\right)$ requires 252.1586. NMR $\left(\mathrm{CDCl}_{3}\right):{ }^{1} \mathrm{H} \delta 7.52\left(\mathrm{~d},{ }^{3} J=2.1 \mathrm{~Hz}, \mathrm{H}-2\right), 6.35$ (d, ${ }^{3} J=2.1 \mathrm{~Hz}, \mathrm{H}-3$ ), 2.88 (d, ${ }^{3} J=6.0 \mathrm{~Hz}$ with $\mathrm{H}-5$ ', $\mathrm{H}_{\mathrm{a}}$ and $\mathrm{H}_{\mathrm{b}}$ on C-4'), 4.82 (t, ${ }^{3} J=6.0 \mathrm{~Hz}$ with $\mathrm{H}_{\mathrm{a}}$ and $\mathrm{H}_{\mathrm{b}}$ on $\mathrm{C}-4$ '), 3.36 (s, $\mathrm{CH}_{3} \mathrm{O}$ on $\mathrm{C}-5$ '), $3.70\left(\underline{\mathrm{ABX}_{3}},{ }^{2} J_{\text {gem }}=-9.4 \mathrm{~Hz},{ }^{3} \mathrm{~J}=7.1 \mathrm{~Hz}\right.$ with $\mathrm{CH}_{3}$ on C-6', $\mathrm{H}_{\mathrm{a}}$ on $\left.\mathrm{C}-6^{\prime}\right), 3.52\left(\underline{\mathrm{ABX}}_{3},{ }^{2} J_{\text {gem }}=-9.4 \mathrm{~Hz},{ }^{3} \mathrm{~J}=7.1 \mathrm{~Hz}\right.$ with $\mathrm{CH}_{3}$ on C-6', $\mathrm{H}_{\mathrm{b}}$ on C-6'), $1.18\left(\mathrm{t},{ }^{3} \mathrm{~J}=7.1 \mathrm{~Hz}\right.$ with $\mathrm{H}_{\mathrm{a}}$ and $\mathrm{H}_{\mathrm{b}}$ on $\mathrm{C}-6$ ', $\mathrm{CH}_{3}$ on $\left.\mathrm{C}-6{ }^{\prime}\right) .{ }^{13} \mathrm{C} \delta 138.59(\mathrm{C}-2), 102.57(\mathrm{C}-3)$, 137.25 (C-3a), 130.53 (C-4), 71.54 (C-7), 24.31 (two $\mathrm{CH}_{3}$ groups on C-7), 37.04 (C-4'), 101.61 (C-5'), 61.51 (C-6'), $52.76\left(\mathrm{CH}_{3} \mathrm{O}\right.$ on $\left.\mathrm{C}-5^{\prime}\right), 15.01\left(\mathrm{CH}_{3}\right.$ on $\left.\mathrm{C}-6^{\prime}\right) .{ }^{15} \mathrm{~N} \delta-88.53(\mathrm{~N}-1),-163.82$ 
$(\mathrm{N}-8),-68.80(\mathrm{~N}-5),-246.55(\mathrm{~N}-6)$. Note that in compound $\mathbf{6}$, as in compound $3, \mathrm{H}_{\mathrm{a}}$ and $\mathrm{H}_{\mathrm{b}}$ on $\mathrm{C}-1$ ' are diastereotopic but accidentally isochronous at $250 \mathrm{MHz}$.

Mechanism. Scheme 2 is not a mechanistic one, but only a naive representation of the origin of the compounds in the different procedures described above as well as in other attempts. For instance, using an ethanolic solution of hydrazine hydrate and p-toluenesulfonic acid as catalyst, the reaction gave $50 \%$ of bipyrazole 1 and $50 \%$ of the pyridazin-4-one derivative 7 . This last compound is a proof of the attack of one double bond of the starting ketone by the solvent $\mathrm{ROH}$. Actually, the diketone $\mathbf{2}$ behaves like a protected dialdehyde that reacts like a tetracarbonyl compound, that is, $\mathrm{OHC}-\mathrm{CH}_{2}-\mathrm{CO}-\mathrm{CO}-\mathrm{CH}_{2}-\mathrm{CHO}$. Reaction of the $\beta$-dicarbonyl part would lead to pyrazoles but reacting as a $\gamma$-dicarbonyl compound corresponds to the well-known synthesis of pyridazines. ${ }^{23,24}$

Tautomerism. The compounds described in this paper deserve some comments concerning their tautomerism. Compound 1 exists in solution as tautomer 3,5' (see Scheme 1). ${ }^{11}$ The pyridazine derivatives 3 and 7 exist in $\mathrm{CDCl}_{3}$ solution as oxo tautomers (pyridazinones), according to the signal of the C-4 (171.5 ppm). In the related case of 4-hydroxypyridine in equilibrium with 4pyridone, C-4 appears at 167.8 and $180.9 \mathrm{ppm}^{25}$ respectively, but these values have to be corrected by -8.6 ppm corresponding to the effect of the $\mathrm{N}-2$ atom. ${ }^{26}$ Thus, the predicted values are $159.2 \mathrm{ppm}$ for the 4-hydroxypyridazine and $172.3 \mathrm{ppm}$ for the 4-pyridazinone. This conclusion is consistent with other pyridazinones [see ref. 1, p. 122]. Finally, pyrazole 5 is probably a 5-substituted tautomer because ${ }^{3} J_{\mathrm{HH}}=2.1 \mathrm{~Hz}$ like ${ }^{3} J_{\mathrm{H} 3-\mathrm{H} 4}$ in compound $\mathbf{6}$ and because 135.23 ppm corresponds to a C-3 signal. ${ }^{27}$ Note that $\mathbf{6}$ is a ring-chain isomer of 5 (a $\mathrm{CDCl}_{3}$ solution of 5 is found by ${ }^{1} \mathrm{H}$ NMR to evolve in 24 h to $100 \%$ of $\mathbf{6}$ ).

\section{Experimental Section}

General Procedures. ${ }^{1} \mathrm{H}$ NMR spectra were recorded on a Bruker Avance-250 spectrometer working at 250.130 for ${ }^{1} \mathrm{H}, 62.896$ for ${ }^{13} \mathrm{C}$ and $25.355 \mathrm{MHz}$ for ${ }^{15} \mathrm{~N}$. Chemical shifts are expressed in ppm/TMS for ${ }^{1} \mathrm{H}$ and ${ }^{13} \mathrm{C}$ and in ppm/external $\mathrm{NO}_{2} \mathrm{Me}$ for ${ }^{15} \mathrm{~N}$ spectra. Coupling constants are in Hertz. Solvent was $\mathrm{CDCl}_{3}$ unless stated otherwise. All the structures were determined by mass spectrometry and NMR spectroscopy. Signals of ${ }^{1} \mathrm{H}$ and ${ }^{13} \mathrm{C}$ NMR spectra were assigned with the help of HMQC and HMBC experiments. Assignments of signals of the ${ }^{15} \mathrm{~N}$ spectrum of compound $\mathbf{6}$ were made according to Gouesnard et al. ${ }^{28}$ and Claramunt et al. ${ }^{29}$ Non first-order spectra were calculated using NMRSIM $^{30}$ and gNMR $^{31}$ softwares affording chemical shifts with three decimal places. Exact masses were determined using electron impact technique and PFK as reference (VG AutoSpec), accuracy \pm 0.0025 daltons.

\section{References}

1. Elguero, J.; Marzin, C.; Katritzky, A.R.; Linda, P. The Tautomerism of Heterocycles; Academic Press: New York, 1976. 
2. Effenberger, F. Chem. Ber. 1965, 98, 2260.

3. Reimlinger, H.; Vandewalle, J.J.M.; van Overstraeten, A. Liebigs Ann. Chem. 1968, 720, 124.

4. Hill, J.H.M.; Berkowitz, D.M; Freese, K.J. J. Org. Chem. 1971, 36, 1563.

5. Ajello, A. J. Heterocyclic Chem. 1971, 8, 1035.

6. Timmermans, P.B.M.W.M.; Uijttewaal, A.P.; Habraken, C.L. J. Heterocyclic Chem. 1972, 9, 1373.

7. Wille, F.; Schwab, W. Monatsh. Chem. 1978, 109, 337.

8. Khan, M.A.; Freitas, A.C.C. Monatsh. Chem. 1981, 112, 675.

9. Lupo, B.; Tarrago, G. Bull. Soc. Chim. Fr., Ser. II 1984, 473.

10. Weinberg, P.; Csongár, C.; Tomaschewski, G. Z. Chem. 1988, 28, 445.

11. Monge, M.A.; Puebla, E.G.; Elguero, J.; Toiron, C.; Meutermans, W. Spectrochim. Acta 1994, 50A, 727.

12. Murakami, Y.; Yamamoto, T. Bull. Chem. Soc. Jap. 1999, 72, 1629.

13. Khan, M.A.; Cosenza, A.G. Afinidad 1988, 45, 173.

14. Arrieta, A.; Carrillo, J.R.; Cossío, F.P.; Díaz-Ortíz, A.; Gómez-Escalonilla, M.J.; de la Hoz, A.; Langa, F.; Moreno, A. Tetrahedron 1998, 54, 13167.

15. Mosby, W.L. J. Chem. Soc. 1957, 3997.

16. Trofimenko, S. J. Org. Chem. 1964, 29, 3046.

17. Freeman, J.P.; Hansen, J. F. J. Chem. Soc., Chem. Commun. 1972, 961.

18. Usón, R.; Oro, L.A.; Esteban, M.; Cuadro, A.M.; Navarro, P.; Elguero, J. Trans. Met. Chem. 1982, 7, 234.

19. Cuadro, A.M.; Elguero, J.; Navarro, P.; Royer, E.; Santos, A. Inorg. Chim. Acta 1984, 81, 99.

20. Boldog, I.; Rusanov, E.B.; Chernega, A.N.; Sieler, J.; Domasevich, K.V. Angew. Chem., Int. Ed. 2001, 40, 3425.

21. Boldog, I.; Rusanov, E.B.; Chernega, A.N.; Sieler, J.; Domasevich, K.V. J. Chem. Soc., Dalton Trans. 2001, 893.

22. Boldog, I.; Rusanov, E.B.; Chernega, A.N.; Sieler, J.; Domasevich, K.V. Polyhedron 2001, 20, 887.

23. Coates, W. J. Comprehensive Heterocyclic Chemistry II; Katritzky, A. R.; Rees, C. W.; Scriven, E. F. Eds.; Pregamon: Oxford;1996, pp1-91.

24. Kolar, P.; Tisler, M. Adv. Heterocyclic Comp. 2000, 75, 167.

25. Murguly, E.; Norsten, T.B.; Branda, N. J. Chem. Soc., Perkin Trans. 2 1999, 2789.

26. Bretmaier, E.; Voelter, W. ${ }^{13} C N M R$ Spectroscopy; $2^{\text {nd }}$ Edition, Verlag Chemie: Weinheim, 1978, p 200.

27. Begtrup, M.; Boyer, G.; Cabildo, P.; Cativiela, C.; Claramunt, R.M.; Elguero, J; García, J.I.; Toiron, C.; Vedsø, P. Magn. Reson. Chem. 1993, 31, 107.

28. Gouesnard, J.P.; Martin, G.J. Org. Magn. Reson. 1979, 12, 263.

29. Claramunt, R.M.; Sanz, D.; López, C.; Jiménez, J.A.; Jimeno, M.L.; Elguero, J.; Fruchier, A. Magn. Reson. Chem. 1997, 35, 35.

30. NMRSIM 2.61 from Bruker Analytik GmbH.

31. gNMR 3.6 from Cherwell Scientific Publishing Ltd. 